\title{
Volatility measurement of atmospheric submicron aerosols in an urban atmosphere in southern China
}

\author{
Li-Ming Cao ${ }^{1}$, Xiao-Feng Huang ${ }^{1}$, Yuan-Yuan $\mathrm{Li}^{1}$, Min $\mathrm{Hu}^{2}$, and Ling-Yan $\mathrm{He}^{1}$ \\ ${ }^{1}$ Key Laboratory for Urban Habitat Environmental Science and Technology, School of Environment and Energy, \\ Peking University Shenzhen Graduate School, Shenzhen, 518055, China \\ ${ }^{2}$ State Key Joint Laboratory of Environmental Simulation and Pollution Control, College of Environmental Sciences \\ and Engineering, Peking University, Beijing, 100871, China
}

Correspondence: Xiao-Feng Huang (huangxf@pku.edu.cn)

Received: 15 July 2017 - Discussion started: 17 August 2017

Revised: 18 November 2017 - Accepted: 27 December 2017 - Published: 6 February 2018

\begin{abstract}
Aerosol pollution has been a very serious environmental problem in China for many years. The volatility of aerosols can affect the distribution of compounds in the gas and aerosol phases, the atmospheric fates of the corresponding components, and the measurement of the concentration of aerosols. Compared to the characterization of chemical composition, few studies have focused on the volatility of aerosols in China. In this study, a thermodenuder aerosol mass spectrometer (TD-AMS) system was deployed to study the volatility of non-refractory submicron particulate matter $\left(\mathrm{PM}_{1}\right)$ species during winter in Shenzhen. To our knowledge, this paper is the first report of the volatilities of aerosol chemical components based on a TD-AMS system in China. The average $\mathrm{PM}_{1}$ mass concentration during the experiment was

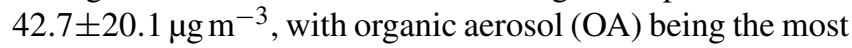
abundant component (43.2\% of the total mass). The volatility of chemical species measured by the AMS varied, with nitrate showing the highest volatility, with a mass fraction remaining (MFR) of 0.57 at $50^{\circ} \mathrm{C}$. Organics showed semivolatile characteristics (the MFR was 0.88 at $50^{\circ} \mathrm{C}$ ), and the volatility had a relatively linear correlation with the TD temperature (from the ambient temperature to $200^{\circ} \mathrm{C}$ ), with an evaporation rate of $0.45 \%{ }^{\circ} \mathrm{C}^{-1}$. Five subtypes of $\mathrm{OA}$ were resolved from total OA using positive matrix factorization (PMF) for data obtained under both ambient temperature and high temperatures through the TD, including a hydrocarbonlike OA (HOA, accounting for $13.5 \%$ ), a cooking OA (COA, $20.6 \%$ ), a biomass-burning OA (BBOA, 8.9\%), and two oxygenated OAs (OOAs): a less-oxidized OOA (LO-OOA, $39.1 \%$ ) and a more-oxidized OOA (MO-OOA, $17.9 \%$ ). Dif-
\end{abstract}

ferent OA factors presented different volatilities, and the volatility sequence of the $\mathrm{OA}$ factors at $50^{\circ} \mathrm{C}$ was $\mathrm{HOA}$ $($ MFR of 0.56$)>$ LO-OOA $(0.70)>$ COA $(0.85) \approx$ BBOA $(0.87)>$ MO-OOA $(0.99)$, which was not completely consistent with the sequence of their $\mathrm{O} / \mathrm{C}$ ratios. The high volatility of HOA implied that it had a high potential to be oxidized to secondary species in the gas phase. The aerosol volatility measurement results in this study provide useful parameters for the modeling work of aerosol evolution in China and are also helpful in understanding the formation mechanisms of secondary aerosols.

\section{Introduction}

Atmospheric aerosol pollution has important impacts on climate change, visibility and human health (Bohnenstengel et al., 2014; Baklanov et al., 2015). Aerosols can be emitted, naturally or anthropogenically, by primary sources or produced by secondary chemical reactions from gaseous precursors (IPCC, 2013). Volatility is one of the most important properties of aerosols, as it can determine the gas-particle phase partitioning of aerosols directly. The saturation vapor pressure, which is affected by temperature and vaporization enthalpies as described by the Clausius-Clapyron equation, is the main factor that dominates the gas-particle phase partitioning of compounds. Volatility can be determined by the saturation vapor pressure or saturation concentration, while the deposition rates of aerosols for wet or dry deposition are greatly influenced by the phase of aerosols (Bidleman, 
1988). The chemical mechanism and reaction rates of gas, liquid, and heterogeneous reactions can also result in a great difference because of the phase, the concentration, and the lifetime of aerosols can also be influenced (Huffman et al., 2009a). The volatility of organic aerosol (OA) also contributes greatly to the uncertainty in predicting the atmospheric aerosol concentration (Donahue et al., 2006; Pankow and Barsanti, 2009). Since OAs contribute $30-80 \%$ of total aerosol mass according to previous studies (Hallquist et al., 2009; Zhang et al., 2007a), further research regarding the volatility of atmospheric aerosols, especially OAs, is very important in the understanding of aerosol characterization and source apportionment. Some previous studies examined several kinds of OA emission sources, including traffic emissions, combustion sources, and the oxidation of primary OA (POA), and showed differences in volatility according to their different compositions (Huffman et al., 2009a; Xu et al.,2016a; Paciga et al., 2016).

A thermodenuder (TD) is a device that is widely used to estimate aerosol volatility distributions (Wehner et al., 2002; An et al., 2007; Huffman et al., 2008; Xu et al., 2016a). The TDs designed by Burtscher et al. (2001) and Wehner et al. (2002) are typically operated under temperatures higher than $200^{\circ} \mathrm{C}$ and have average residence times from 0.3 to $9 \mathrm{~s}$, focusing on very-low-volatility species. An et al. (2007) and Huffman et al. (2008) developed TDs with longer residence times to make them more suitable for measuring the volatility of semi-volatile OAs. The combined TD and Aerodyne aerosol mass spectrometer (TD-AMS) system was first applied in an ambient study by Huffman et al. (2008) to quickly characterize the volatility of chemically resolved ambient aerosol in a field campaign, and the temperature profiles, particle losses, and key factors affecting the results were discussed. Huffman et al. (2009a) then measured the volatility of OA from different sources, including biomass-burning OA (BBOA), meat-cooking OA, trash-burning OA, and chamber secondary organic aerosol (SOA) formed from $\alpha$-pinene and gasoline vapors and found semi-volatility for all the OAs, which is opposite from the previous atmospheric models that only regarded POAs as nonvolatile species. Huffman et al. (2009b) also analyzed the positive matrix factorization (PMF) results based on the TD-AMS data and demonstrated that all types of OA should be regarded as semi-volatile species in the models. Lee et al. (2010) measured the volatility of aerosols with two different residence time sets and suggested that longer residence time was required to constrain the variation in OA volatility at lower concentrations. Obviously, OA volatilities, especially for different OA types, are still quite uncertain and need more ambient measurements to constrain.

Aerosol pollution has been one of the most important air quality problems in China. Many studies focusing on aerosol source apportionment and chemical and physical properties have been carried out in most of the regions in China, especially in the Yangtze River Delta region, the Pearl River
Delta region, the Beijing-Tianjin-Hebei region, and northwestern China in the past few years (Huang et al., 2010, 2012, 2013; He et al., 2011; Xu et al., 2014; Li et al., 2017). However, the volatility of aerosols is rarely researched in China currently. Cheung et al. (2016) studied the aerosol volatility in Guangzhou, China, based on the volatility tandem differential mobility analyzer (VTDMA) measurement and found that nonvolatile OA may contribute significantly to the nonvolatile residuals. Also using a VTDMA, Nie et al. (2017) studied the volatility of aerosol humic-like substances (HULISs) in Nanjing, China, and figured out that the interaction between HULISs and ammonium sulfate tended to decrease the volatility of OAs. In this paper, the TD-AMS system was first deployed to determine the volatilities of nonrefractory $\mathrm{PM}_{1}$ species in China. With the high-resolution mass spectra of organics, the volatilities of OAs from different sources and their implications for OA ageing were also explored.

\section{Experimental methods}

\subsection{Sampling site description}

Shenzhen $\left(113.9^{\circ} \mathrm{E}, 22.6^{\circ} \mathrm{N}\right)$ is located on the southeastern coast of China, in the southeastern corner of the Pearl River Delta region with Hong Kong neighboring to the south and Dongguan (a famous industrial city in China) to the north. The climate in Shenzhen is a subtropical oceanic climate that is deeply influenced by the monsoon. The sampling site was located on the campus of Shenzhen Graduate School, Peking University in the western urban area of Shenzhen. The area surrounding the sampling site was mostly covered by subtropical plants, and there was only a local road that was approximately $100 \mathrm{~m}$ away, which can be regarded as an anthropogenic emission source. The measurement was taken from 31 December 2014 to 23 January 2015 in winter, which is the season with the highest air pollution due to regional transportation from northwestern and northeastern China. The average ambient temperature was $15.9 \pm 4.2^{\circ} \mathrm{C}$, and the relative humidity was $62.9 \pm 17.5 \%$. The wind was mostly from the northeast and northwest with an average speed of $0.8 \pm 0.7 \mathrm{~m} \mathrm{~s}^{-1}$.

\subsection{Instruments and methodology}

The aerosol volatility measurements were conducted with a TD-AMS system. The thermodenuder and the highresolution time-of-flight aerosol mass spectrometer (HRToF-AMS, referred to hereafter as AMS) were both manufactured by Aerodyne Research Inc., US. The principle theory of an AMS can be found in previous studies (DeCarlo et al., 2006; Canagaratna et al., 2007). The AMS was set into two sampling ion optical modes: the $\mathrm{V}$ mode with unit mass resolution (UMR) was used for quantification of the UMR mass concentration and size distribution of the non- 
refractory species (including organics, sulfate, nitrate, ammonium, and chloride); the $\mathrm{W}$ mode was used to obtain the high-resolution mass spectra $\left(\sim 3000 \mathrm{~m} \Delta \mathrm{m}^{-1}\right)$, and the ions with a $m / z$ up to 170 could be separated properly in this study. The calibrations were conducted at the beginning and end of the campaign with the method described previously (Jayne et al., 2000; Jimenez et al., 2003; Drewnick et al., 2005), including the inlet flow rate, ionization efficiency calibration (IE), and particle size calibrations. The relative ionization efficiencies (RIEs) used in the study were 1.2 for sulfate, 1.1 for nitrate, 1.3 for chloride, 1.4 for organics, and 4.0 for ammonium (Jimenez et al., 2003). The TD used in this experiment is based on the design of Huffman et al. (2008). It consists of two parts: the heating section and the denuder section. The stainless steel heating section is 22.25 inches $(56.5 \mathrm{~cm})$ in length with a 1 inch OD $(2.5 \mathrm{~cm})$ and a 0.875 inch ID $(2.2 \mathrm{~cm})$, wrapped with three fiberglasscoated heating tapes. The heating section is then joined to a 22 inch $(56 \mathrm{~cm})$ denuder section. The denuder section is filled with activated charcoal at room temperature to adsorb the gas-phase species evaporated from particles. The temperature in the heating section was set at $48,95,143$, and $192^{\circ} \mathrm{C}$ to make the real temperature at the centerline, measured with a thermocouple, reach $50,100,150$, and $200^{\circ} \mathrm{C}$, respectively. The full configuration of temperatures in the TD software was $35 \mathrm{~min}$ at $50^{\circ} \mathrm{C}, 5 \mathrm{~min}$ for the temperature increasing to $100^{\circ} \mathrm{C}, 22 \mathrm{~min}$ at $100^{\circ} \mathrm{C}, 5 \mathrm{~min}$ for the temperature increasing to $150^{\circ} \mathrm{C}, 24 \mathrm{~min}$ at $150^{\circ} \mathrm{C}, 5 \mathrm{~min}$ for the temperature increasing to $200^{\circ} \mathrm{C}, 25 \mathrm{~min}$ at $200^{\circ} \mathrm{C}$, and then $15 \mathrm{~min}$ for the temperature decreasing to $50^{\circ} \mathrm{C}$. The complete temperature cycle lasted about $136 \mathrm{~min}$. The TD was placed upstream of the AMS. The aerosol flow can go through the heating and denuder sections (TD path) before being sampled by the AMS or flowing directly (bypass path) into the AMS. The residence time of aerosols in the heating section was approximately $27.9 \mathrm{~s}$ with a flow rate of $0.45 \mathrm{~L} \mathrm{~min}^{-1}$. The AMS was set with four menus: bypass path in V mode, TD path in $\mathrm{V}$ mode, TD path in $\mathrm{W}$ mode and bypass path in $\mathrm{W}$ mode, with $2 \mathrm{~min}$ in each menu. Only the data sampled during the stable temperature plateau (1839 points for V mode and 1842 points for $\mathrm{W}$ mode in TD path) were selected for the calculation of volatility.

The data analysis was performed with SQUIRREL 1.57 and PIKA 1.16 (http://cires1.colorado.edu/jimenez-group/ ToFAMSResources/ToFSoftware/index.html) with the method in DeCarlo et al. (2006). The mass concentration was corrected with composition-dependent collection efficiency (Middlebrook et al., 2012). All the elemental ratios calculated here were based on the "Improved-Ambient" (I-A) method (Canagaratna et al., 2015) while the previous "Aiken-Ambient" (A-A) method was also used for comparison in Table $\mathrm{S} 1$ in the Supplement (Aiken et al., 2008).
An aethalometer (AE-31, Magee, US) coupled with a $\mathrm{PM}_{2.5}$ cyclone was used to measure the mass concentration of black carbon (BC) with a time resolution of $5 \mathrm{~min}$. The wavelength of $880 \mathrm{~nm}$ was used to calculate the $\mathrm{BC}$ mass concentration in the data processing. The total $\mathrm{BC}\left(\mathrm{BC}_{\text {total }}\right)$ measured by the aethalometer can be separated into $\mathrm{BC}$ emitted by traffic $\left(\mathrm{BC}_{\mathrm{tr}}\right)$ and biomass burning $\left(\mathrm{BC}_{\mathrm{bb}}\right)$ based on the aerosol absorption as described in the Supplement (Sandradewi et al., 2008). A scanning mobility particle sizer (SMPS, TSI, Inc.) was used to measure the particle number size distribution (mobility diameter: $15-600 \mathrm{~nm}$ ) with a time resolution of $5 \mathrm{~min}$. By assuming the densities of the components obtained in the literature (Kuwata et al., 2012; Poulain et al., 2014; Hu et al., 2017), the corresponding mass concentration can be calculated from the particle number size distribution. The AE-31 and SMPS were used only for ambient sampling.

\subsection{Particle loss correction}

The particle losses through the TD should be of concern for quantitative measurements with the TD, as they can decrease the transmission efficiency through the TD. There are three mechanisms of particle loss inside the TD: sedimentation, thermophoretic, and diffusional processes (Burtscher et al., 2001; Wehner et al., 2002). Burtscher et al. (2001) determined that the dominant effects would be determined by the temperature and particle size: sedimentation increases as the particle size increases and would be negligible when the TD is vertical; diffusive losses increase with decreasing particle size; thermophoresis is not strongly dependent on particle size, is important in the denuder section, and will partly compensate for diffusion in the heating section.

The transmission efficiency in this research was calculated via an experiment. $\mathrm{CsCl}$ was chosen as the standard chemical species for the test of the transmission efficiency of TD due to its thermal stability as discussed by Huffman et al. (2008). The $\mathrm{CsCl}$ solution was atomized and then measured using a differential mobility analyzer (DMA, TSI, Inc.) and condensation particle counter (CPC, TSI, Inc.) before and after the TD. The transmission efficiency of the bypass path was regarded as 1 . The average transmission efficiency through the TD is approximately $90 \%$ at $50,100,150$, and $200^{\circ} \mathrm{C}$, as shown in Fig. 1, which is similar to previous studies (Huffman et al., 2008; Xu et al., 2016a). The transmission efficiency would be applied in the calculation of the mass concentration of particles flowed through the TD.

\subsection{Source apportionment method}

PMF was applied to the high-resolution organic mass spectra using the PMF evaluation tool developed by Ulbrich et al. (2009). The data and error matrices were processed according to the signal-to-noise ratio (SNR) as reported in previous papers (Ulbrich et al., 2009; Huang et al., 2010; 


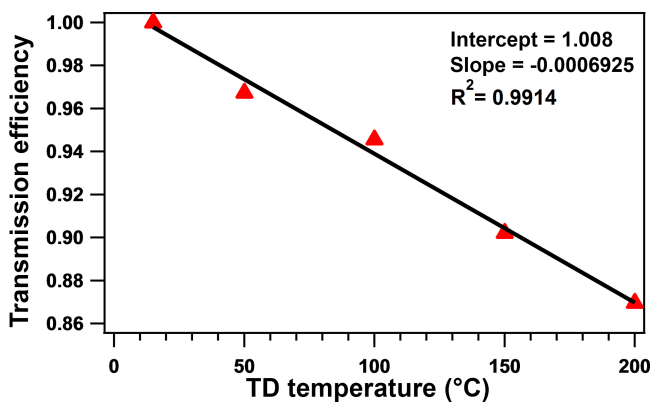

Figure 1. Temperature-related transmission efficiency through the TD.

He et al., 2011). Weak ions $(0.2<\mathrm{SNR}<2)$ were downweighted by a factor of 2 , bad ions $(\mathrm{SNR}<0.2)$ were removed from the analysis (Paatero and Hopke, 2003), and $\mathrm{CO}_{2}^{+}$-related ions $\left(\mathrm{O}^{+}, \mathrm{HO}^{+}, \mathrm{H}_{2} \mathrm{O}^{+}\right.$, and $\left.\mathrm{CO}^{+}\right)$were also downweighted (Ulbrich et al., 2009).

The PMF analysis was based on the full high-resolution organic dataset (including both data sampled under ambient temperature and data that were thermally denuded) for 1 to 10 factors with $f_{\text {peak }}$ varying from -1 to 1 (seed $=0$ ), increasing with a step of 0.1 , and seed varying from 0 to 250 $\left(f_{\text {peak }}=0\right)$ in steps of 10 . The diagnostic plots of the solutions are shown in Fig. S1 in the Supplement, including the $Q / Q_{\text {expected }}$ ratio, the characteristics of the different mass spectra, the scaled residuals, and the correlation of the component time series with the external tracers. The solutions with more than five factors showed no distinct information but splitting of the factors. The $Q / Q_{\text {expected }}$ showed the lowest value at $f_{\text {peak }}=0$; the varied $f_{\text {peak }}$ did not improve the results. The varied value of seed also made no significant difference of the solution. Therefore, the solution of five factors, $f_{\text {peak }}=0$, and seed $=0$ was determined as the optimal solution for this experiment, and the five factors are hydrocarbonlike OA (HOA), cooking OA (COA), BBOA, less-oxidized oxygenated OA (LO-OOA), and more-oxidized oxygenated OA (MO-OOA).

In addition, the PMF results with the data obtained only under ambient temperatures were also explored and the best solution was presented in Fig. S2 in the Supplement. Compared to the results including the thermally denuded data, the HOA and OOA were mixed to some extent, with a signature of the high fraction of $\mathrm{CO}_{2}^{+}$in the HOA mass spectrum. Therefore, the PMF solution with the inclusion of the thermally denuded data was confirmed as the final result for later discussion. Huffman et al. (2009b) also suggested that the PMF solution of all data collected both with and without TD processing could facilitate the separation of different OA factors by enhancing the contrast of the time series of these factors.

\section{Results and discussion}

\subsection{PM $_{1}$ chemical compositions}

Figure 2 shows the chemical compositions for only bypass conditions. Figure 2a shows the time series of the mass concentration of non-refractory species measured by the AMS and BC measured with an aethalometer during the experiment. Sulfate showed a relatively stable time series, with a relative SD (RSD) of $38.8 \%$, compared to the other species, such as organics $(\mathrm{RSD}=56.1 \%)$, nitrate $(\mathrm{RSD}=$ $69.6 \%)$, and black carbon ( $\mathrm{RSD}=70.2 \%)$, indicating that sulfate was less affected by local emission sources. However, all the species decreased their concentrations largely during 12-13 January due to a heavy rain event. The sum of the non-refractory species and $\mathrm{BC}$ was regarded as $\mathrm{PM}_{1}$, which showed a high correlation $\left(R^{2}=0.94\right.$, slope $=1.1$; in Fig. S3) with the mass concentration derived from the particle number concentration measured by SMPS. As a result, the average mass concentration of $\mathrm{PM}_{1}$ was $42.7 \pm$ $20.1 \mu \mathrm{g} \mathrm{m}^{-3}$, ranging from 3.9 to $134.1 \mu \mathrm{g} \mathrm{m}^{-3}$, while organics were the most abundant $\mathrm{PM}_{1}$ component, contributing $43.2 \%$ to the total $\mathrm{PM}_{1}$ mass concentration, followed by sulfate $(21.2 \%)$, BC $(12.2 \%)$, nitrate $(11.4 \%)$, ammonium $(10.4 \%)$, and chloride (1.6\%). The measured and predicted ammonium showed a high correlation $\left(R^{2}=0.97\right)$ with a slope of 0.85 , implying that the aerosols showed some acidity (Zhang et al., 2007b).

The diurnal variation in the $\mathrm{PM}_{1}$ species is shown in Fig. 2b. The two peaks in the diurnal variation in $\mathrm{BC}$ obviously match the traffic rush hours at approximately 08:00 in the morning and the activities of heavy duty vehicles in the evening. When BC source apportionment was applied for our $\mathrm{BC}$ dataset, the results indicated that biomass-burningemitted $\mathrm{BC}$ also made a small contribution to the evening peak of BC (Fig. S4). Nitrate showed a significant peak about $2 \mathrm{~h}$ after the morning peak of $\mathrm{BC}$, which was likely a result of photochemical oxidization of $\mathrm{NO}_{x}$ emitted from the morning traffic. Then, the concentration of nitrate decreased because of both the lifting of the planetary boundary layer (PBL) and its evaporation at higher ambient temperatures (also shown in Fig. 2b). Nitrate maintained a stable concentration level in the evening. Similar to ammonium nitrate, ammonium chloride is also quite semi-volatile as revealed in Sect. 3.3. Therefore, its diurnal variation was largely influenced by the ambient temperature, as well as the height of the PBL. Also, according to Sect. 3.3, sulfate is a lessvolatile species and thus would not lose significant particulate mass when the ambient temperature increases. As a secondary species from $\mathrm{SO}_{2}$ oxidation, sulfate showed a slight diurnal variation, indicating that it was less affected by the variation in the PBL. This implies that sulfate was not a typical ground-emitted species and could be better mixed in the PBL. Actually, aerosol sulfate in Shenzhen has been proven to be a species mostly from regional air mass transport ( $\mathrm{He}$ 
et al., 2011; Huang et al., 2014). Since ammonium exists mostly in the forms of $\left(\mathrm{NH}_{4}\right)_{2} \mathrm{SO}_{4}, \mathrm{NH}_{4} \mathrm{NO}_{3}$, and $\mathrm{NH}_{4} \mathrm{Cl}$, its diurnal variation should be significantly affected by the formation processes of all these inorganic salts, in addition to atmospheric physical processes and semi-volatility. The measured and predicted ammonium showed a similar correlation $\left(R^{2}=0.96-0.97\right)$ with a similar slope of $0.84-0.85$ for both the ambient temperatures and $50{ }^{\circ} \mathrm{C}$ (Fig. S5), implying that the aerosols showed some acidity in the real ambient temperature range (Zhang et al., 2007b). The diurnal variation in organics showed more fluctuation and a few peaks, consistent with its complex origins, e.g., vehicles, biomass burning, and secondary formation (He et al., 2011; Elser et al., 2016), which will be discussed in detail in Sect. 3.2.

The average values of $\mathrm{O} / \mathrm{C}$ and $\mathrm{H} / \mathrm{C}$ of $\mathrm{OA}$ were 0.52 and 1.61 , respectively. The average $\mathrm{O} / \mathrm{C}$ value in this campaign is within the typical $\mathrm{O} / \mathrm{C}$ range of $0.28-0.56$ previously observed under polluted urban environments in China (Huang et al., 2011, 2012; He et al., 2011; Xu et al., 2016b; Hu et al., 2016; Lee et al., 2013). The diurnal variation in $\mathrm{O} / \mathrm{C}$ plotted in Fig. 2c shows elevated values during the daytime, which is a clear indicator of the formation of secondary OA with more oxygen, while $\mathrm{H} / \mathrm{C}$ reasonably showed an opposite diurnal trend, with decreased values during the daytime. The quick elevation of $\mathrm{H} / \mathrm{C}$ in the evening should be a combined result of various primary emissions, e.g., traffic, cooking, and biomass burning, which is supported by the source apportionment results discussed in Sect. 3.2.

Figure $2 d$ shows the average size distribution of the five non-refractory species. The peaks of all the species were at approximately $500-700 \mathrm{~nm}$ in the accumulation modes, while organics apparently had more mass distribution at smaller sizes down to $\sim 100 \mathrm{~nm}$. The inorganic aerosol species showed a similar average size distribution during the experiment as described in previous studies in Shenzhen (He et al., 2011). Compared to other species, the peak of organics was slightly smaller, which was a result of the much broader size distribution of organics towards smaller sizes. This character of organic size distribution implies that urban fresh primary emissions contributed significantly to OA (Canagaratna et al., 2004; He et al., 2011). The peak of sulfate was slightly larger than the other species, suggesting that sulfate was mostly associated with more aged particles that had grown during air mass transport (Zhang et al., 2005; Huang et al., 2008).

\subsection{Source apportionment}

Organics are one of the most important chemical species in aerosol pollution in Shenzhen, contributing $43.2 \%$ to the total $\mathrm{PM}_{1}$ mass loading. As discussed in Sect. 2.4, PMF modeling was applied to the high-resolution mass spectra of organics and five factors were identified with their mass spectrometer profiles shown in Fig. 3a. Under ambient temperatures, HOA, COA, BBOA, LO-OOA, and MO-OOA averagely ac- counted for $13.5,20.6,8.9,39.1$, and $17.9 \%$ of the total organic mass, respectively (Fig. 3d).

HOA is most often dominated by long-chain hydrocarbon ion series of $\mathrm{C}_{n} \mathrm{H}_{2 n+1}^{+}$and $\mathrm{C}_{n} \mathrm{H}_{2 n-1}^{+}$in previous findings (Canagaratna et al., 2004; Mohr et al., 2009; $\mathrm{Ng}$ et al., 2010), which is also the case in this campaign. The average $\mathrm{O} / \mathrm{C}$ of HOA was 0.10 in this campaign, which was in its range $(0.03$ to 0.17$)$ reported in previous publications (e.g., Aiken et al., 2009; Huang et al., 2010; Mohr et al., 2012). $\mathrm{BC}$ is regarded as a tracer of HOA and can be significantly emitted from both fossil fuel combustion and biomass burning (Zhang et al., 2007a; Lanz et al., 2007; Lan et al., 2011). The good correlation $\left(R^{2}=0.82\right)$ of $\mathrm{HOA}$ and $\mathrm{BC}_{\mathrm{tr}}$ (Fig. $\left.3 \mathrm{~b}\right)$ suggested that HOA was mainly from traffic emissions. The diurnal variation in HOA was influenced by PBL dynamics and also showed peaks that matched the rush hours, further supporting the dominant role of traffic emissions in the HOA.

The $\mathrm{O} / \mathrm{C}$ ratio of $\mathrm{COA}$ is 0.18 , which is similar to the previous results shown in Mohr et al. (2012). The mass spectral signature of COA is dominated by the ion series of $\mathrm{C}_{n} \mathrm{H}_{2 n+1}^{+}$and $\mathrm{C}_{m} \mathrm{H}_{2 m+1} \mathrm{CO}^{+}(m / z 29,43,57,71,85 \ldots)$ and $\mathrm{C}_{n} \mathrm{H}_{2 n-1}^{+}$and $\mathrm{C}_{m} \mathrm{H}_{2 m-1} \mathrm{CO}^{+}(m / z 41,55,69,83 \ldots)$, which are mainly ionized from alkanes, alkenes, and, possibly, long-chain fatty acids (He et al., 2010; Huang et al., 2010; Mohr et al., 2009, 2012). Mohr et al. (2012) also identified COA from HOA by comparing the signals of $m / z 55$ and $m / z 57$ and determined that the differentiation between $\mathrm{COA}$ and $\mathrm{HOA}$ is mainly driven by the oxygen-containing ions of $\mathrm{C}_{3} \mathrm{H}_{3} \mathrm{O}^{+}$and $\mathrm{C}_{3} \mathrm{H}_{5} \mathrm{O}^{+}$; especially if the signal ratio of $m / z 55$ to $m / z 57$ is larger than 2, it can probably be recognized as COA. In this study, COA showed much more $\mathrm{C}_{3} \mathrm{H}_{3} \mathrm{O}^{+}$than $\mathrm{HOA}$, and the ratio of $\mathrm{m} / \mathrm{z} 55$ to $\mathrm{m} / \mathrm{z} 57$ showed values larger than 2 , indicating the origin of cooking emissions. The diurnal variation in COA in Fig. $3 \mathrm{c}$ shows a small peak at approximately 8:00 UTC $+8(\mathrm{UTC}+8$ for all times following), breakfast time, and the second peak at approximately 14:00 corresponds with lunch time. The mass concentration of COA also rises after 17:00, which is the time for dinner and partly because of the decreasing PBL height. The good correlation of COA with the tracer ion $\mathrm{C}_{6} \mathrm{H}_{10} \mathrm{O}$ ( $R^{2}=0.91$ ) (Sun et al., 2011; Crippa et al., 2013; Elser et al., 2016) also demonstrated the presence of COA.

The most abundant signals in BBOA are $m / z 29\left(\mathrm{CHO}^{+}\right)$ and $m / z 43\left(\mathrm{C}_{2} \mathrm{H}_{3} \mathrm{O}^{+}\right)$, and there are more fragments in the range of $m / z>100$ for BBOA than for COA and HOA (He et al., 2010). BBOA can be identified by the contribution of $m / z 60$ (mostly $\mathrm{C}_{2} \mathrm{H}_{4} \mathrm{O}_{2}^{+}$), which is a distinct fragment of ionized levoglucosan, the molecular marker of biomass burning (Alfarra et al., 2007; Aiken et al., 2009; Mohr et al., 2009). Some previous studies have shown that the background level of $\mathrm{m} / \mathrm{z} 60 / \mathrm{OA}$ is approximately $0.3 \%$ in urban areas without biomass-burning impacts (DeCarlo et al., 2008; Docherty et al., 2008). The signal of $m / z 60$ in BBOA is $1.36 \%$ in this study, indicating the presence of BBOA 

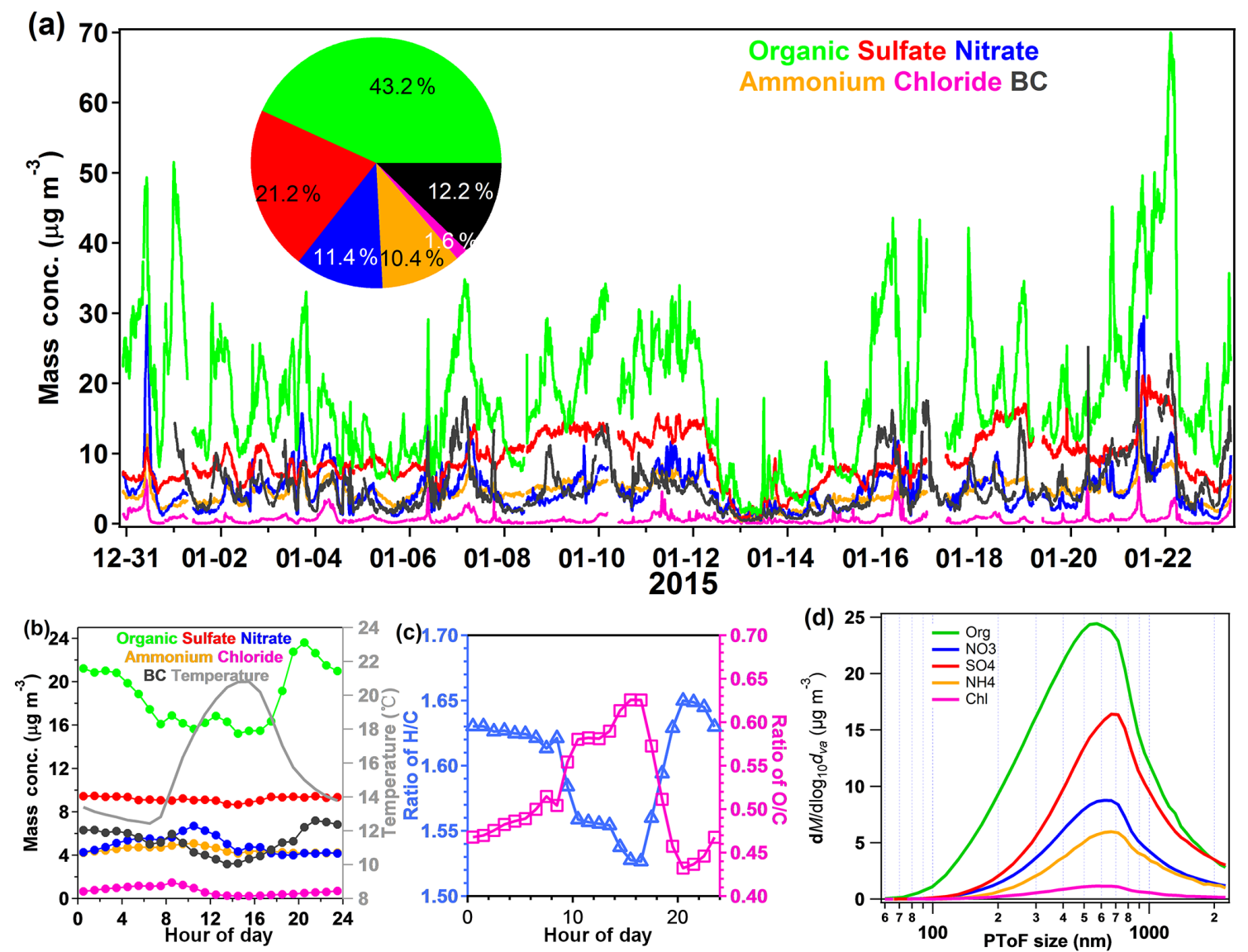

Figure 2. Chemical composition for only bypass conditions: (a) time series and the mass percentages of $\mathrm{PM}_{1}$ composition; (b) diurnal variation in $\mathrm{PM}_{1}$ species and ambient temperature; (c) diurnal variation in $\mathrm{H} / \mathrm{C}$ ratio and $\mathrm{O} / \mathrm{C}$ ratio; (d) average size distribution of nonrefractory $\mathrm{PM}_{1}$ species.

during this experiment, and the BBOA correlated well with $m / z 60\left(R^{2}=0.83\right)$. The $\mathrm{O} / \mathrm{C}$ ratios of BBOA varied a lot in previous studies. Laboratory studies reported $\mathrm{O} / \mathrm{C}$ ratios of $0.18-0.26$ for six types of biomass-burning emissions (He et al., 2010), $\mathrm{O} / \mathrm{C}$ ratios of 0.31 for lodgepole pine burning, and 0.42 for sage/rabbitbrush burning (Aiken et al., 2008). DeCarlo et al. (2010) reported an O/C ratio of 0.42 for ambient biomass-burning aerosol. The BBOA in this study showed an $\mathrm{O} / \mathrm{C}$ ratio of 0.33 , which is within the range of previous studies. The diurnal trend in BBOA showed a large peak in the evening, consistent with the diurnal peak of $\mathrm{BC}_{\mathrm{bb}}$ in Fig. S4.

OOA is recognized by the most intense signal of $m / z 44$ $\left(\mathrm{CO}_{2}^{+}\right)$, and the signals at higher values of $m / z$ are lower relative to those of other OA factors ( $\mathrm{Ng}$ et al., 2010). Furthermore, the OOA can be divided into two factors, LO-OOA (typically named semi-volatile OOA) and MO-OOA (typically named less-volatile OOA), according to the $\mathrm{O} / \mathrm{C}$ ratios and $f_{44}$ (Jimenez et al., 2009; Ng et al., 2010; Xu et al., 2015). The factor with a relatively higher $\mathrm{O} / \mathrm{C}$ ratio $(0.95)$ of OOA and higher $f_{44}$ than $f_{43}$ is identified as MO-OOA. It showed a good correlation $\left(R^{2}=0.64\right)$ with sulfate, which was less volatile and had been identified as a regional pollutant in Shenzhen (He et al., 2011; Huang et al., 2014), implying MO-OOA could also be aged aerosol from regional transport. The correlation of MO-OOA with nitrate $\left(R^{2}=0.27\right)$ is much lower than with sulfate, which is a typical result. Meanwhile, LO-OOA, which is less oxygenated $(\mathrm{O} / \mathrm{C}=0.76)$, showed a narrow gap between $f_{43}$ and $f_{44}$. The correlation of LO-OOA with sulfate $\left(R^{2}=0.59\right)$ was indeed a little bigger than with nitrate $\left(R^{2}=0.46\right)$, which could be a combined result of the precursors, formation mechanisms, and volatility of LO-OOA. Unlike the primary organic components, which had lower concentrations during the daytime due to the elevated PBL, the diurnal variations in both LO-OOA and MOOOA showed higher concentrations during the daytime, suggesting that photochemical secondary production should be their main source. The diurnal variation in MO-OOA was relatively stable compared to that in LO-OOA, which is consistent with MO-OOA being a more aged and regional component. The contribution of the two OOA to total OAs is $57.0 \%$, indicating that OOA contributes the majority of the OA pollution in wintertime in Shenzhen. 


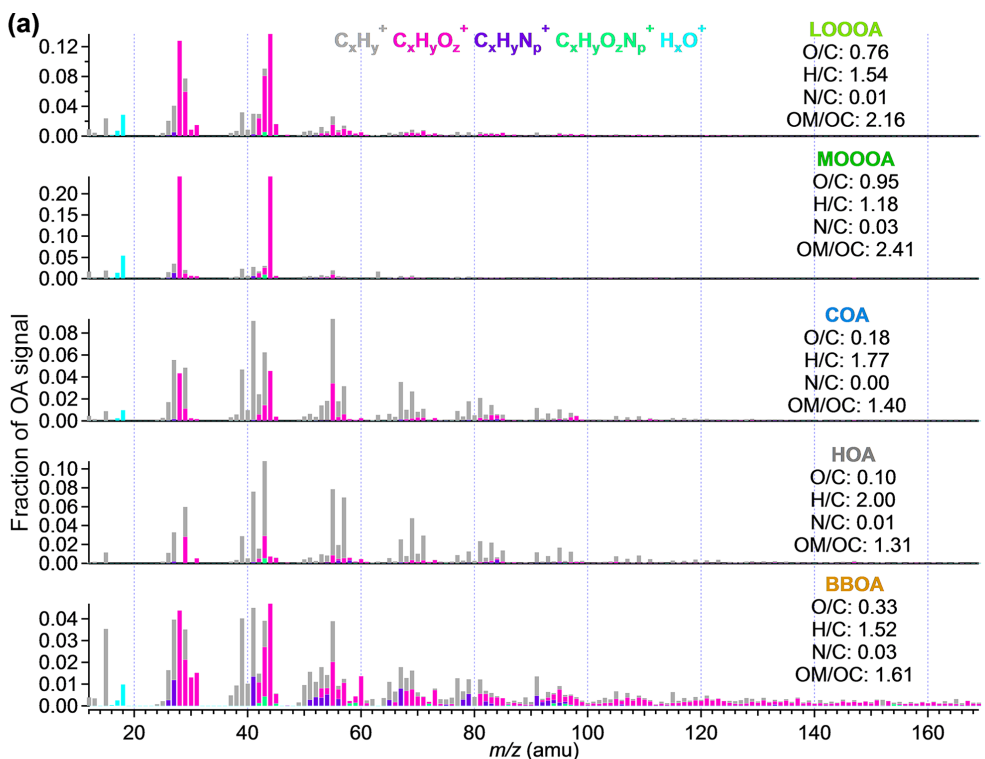

(b)
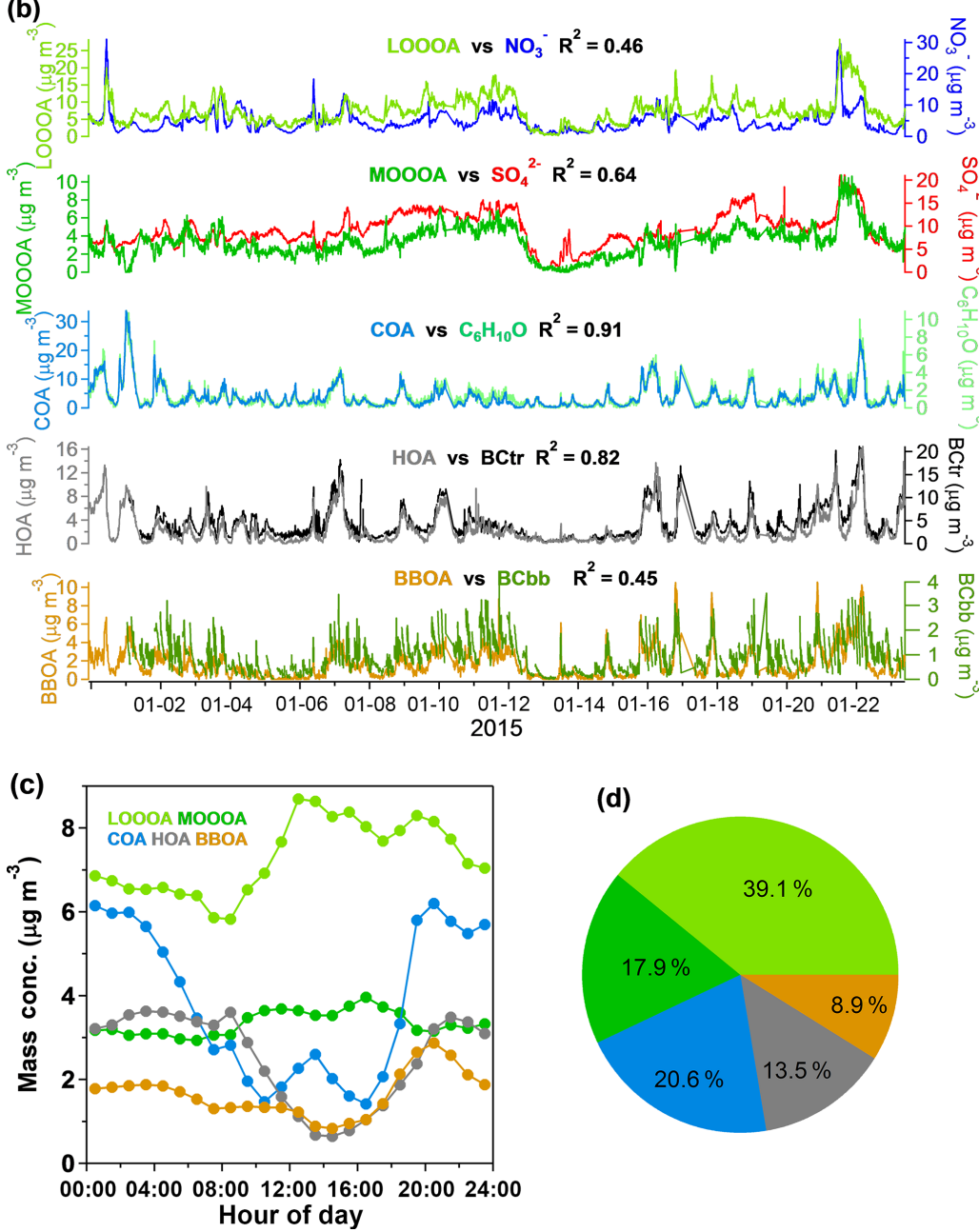

(d)

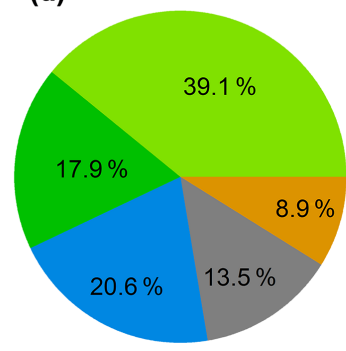

Figure 3. (a) MS profiles of the five OA factors identified by PMF; (b) time series of the five OA factors and the correlation with the relevant species during the experiment; (c) the diurnal variation in the five OA factors; (d) the average contributions of the five OA factors to total OA. The time series, diurnal variation, and pie chart display the results only for ambient conditions. 

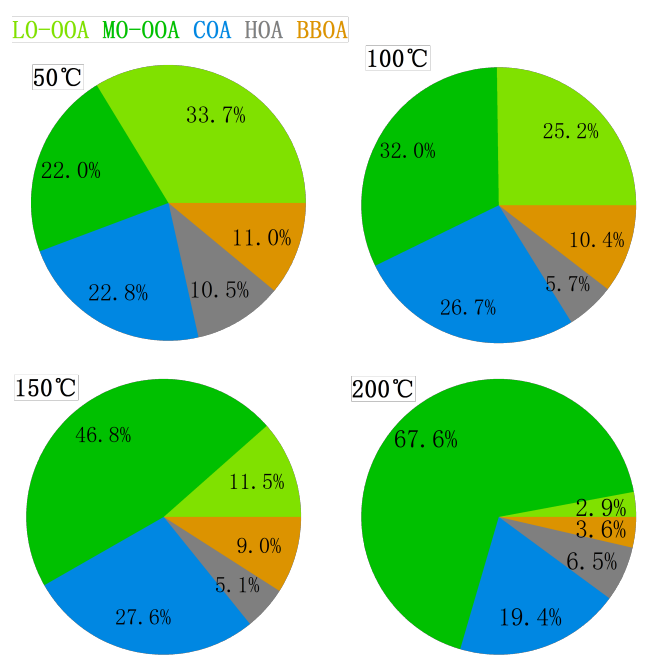

Figure 4. The average compositions of the total OA at different TD temperatures.

Figure 4 showed the mass fractions of the five factors at different TD temperatures. It is found that when the temperature increased, the fraction of MO-OOA quickly increased up to $67.6 \%$ at $200^{\circ} \mathrm{C}$, while LO-OOA showed a reverse trend, accounting for only $2.9 \%$ at $200^{\circ} \mathrm{C}$, indicating that they had quite different volatilities. HOA, COA, and BBOA also exhibited different volatilities, with HOA accounting for only $5-7 \%$ above $100^{\circ} \mathrm{C}$, while the fraction of COA did not change much with the increasing temperature. The different volatilities of different OA factors will be discussed in more detail in the following section.

\subsection{Volatility of $\mathrm{PM}_{1}$ species and $\mathrm{OA}$ factors}

Figure 5 shows the mass fraction remaining (MFR) of the non-refractory species. The MFR is calculated as the ratio of the species mass concentrations with and without TD processing. The narrow average $\mathrm{MFR} \pm \mathrm{SD}$ regions show that the volatilities of these species were stable during the measurement. The MFRs of the total non-refractory species and organics both showed nearly linear correlations with the TD temperature, which is consistent with the fact that they include various compounds with a wide range of volatilities. For organics, the MFR was 0.88 at $50^{\circ} \mathrm{C}, 0.63$ at $100^{\circ} \mathrm{C}, 0.32$ at $150^{\circ} \mathrm{C}$, and, finally, 0.16 at $200^{\circ} \mathrm{C}$. Based on the linear relationship of the MFR of organics and the TD temperature, the evaporation rate of organics is approximately $0.45 \%{ }^{\circ} \mathrm{C}^{-1}$. The relationship of the $\mathrm{O} / \mathrm{C}, \mathrm{H} / \mathrm{C}$, and $\mathrm{N} / \mathrm{C}$ ratios with the TD temperature is also shown in Fig. 5. It can be seen that $\mathrm{O} / \mathrm{C}$ kept increasing as the temperature increased, especially after $150^{\circ} \mathrm{C}$, which is consistent with previous studies (Xu et al., 2016a). When examining the organic mass spectra at difference temperatures (in Fig. S6), the ele- vation of $\mathrm{O} / \mathrm{C}$ with increasing temperature was found to be reasonably related to increasing of $\mathrm{CO}_{2}^{+}$. Previous PMF results usually correlated higher volatility with reduced species and lower volatility with more oxygenated species ( $\mathrm{Ng}$ et al., 2010; Huang et al., 2012). In this study, the elevation of O / C with increasing temperature was closely related to the evaporation of more reduced organic components, as the PMF results indicated. Conversely, $\mathrm{H} / \mathrm{C}$ showed a reasonable reverse trend relative to that of $\mathrm{O} / \mathrm{C} . \mathrm{N} / \mathrm{C}$ generally had an increasing trend with the TD temperature increasing, but N/C varied largely at the different TD temperatures, suggesting that the volatilities of $\mathrm{N}$-containing compounds are complex.

Figure 5 also shows the MFRs of inorganic species with different temperature, and all the inorganic species showed trends similar to the results shown by Huffman et al. (2008). Nitrate and chloride show similar trends: they both decreased sharply from ambient temperature to $50^{\circ} \mathrm{C}$, reaching approximately 0.57 ; then they decreased at a lower rate from 50 to $150^{\circ} \mathrm{C}$. When the TD temperature increased to $200^{\circ} \mathrm{C}$, the MFRs of nitrate and chloride were at approximately 0.08 , which is lower than those of all the other species. Sulfate is the least volatile species among all $\mathrm{PM}_{1}$ species. The MFR of sulfate does not show a significant decreasing trend with temperature below $100^{\circ} \mathrm{C}\left(0.93\right.$ at $50^{\circ} \mathrm{C}$ and 0.89 at $100^{\circ} \mathrm{C}$ ); when the temperature reached $150^{\circ} \mathrm{C}$, the MFR decreased sharply to 0.43 , with $11 \%$ left at $200^{\circ} \mathrm{C}$. The trend in MFR of sulfate is consistent with the discussion in Burtscher et al. (2001): sulfuric acid would evaporate under temperatures of $30-125^{\circ} \mathrm{C}$, while ammonium sulfate and bisulfate would evaporate between 125 and $175^{\circ} \mathrm{C}$.

Figure 6 shows the MFRs of the different OA factors identified by PMF. The MFR of HOA was 0.56 at $50^{\circ} \mathrm{C}$ and decreased by $1.26 \%{ }^{\circ} \mathrm{C}^{-1}$ from the ambient temperature to $50{ }^{\circ} \mathrm{C}$ and reached only $17.8 \%$ at $100{ }^{\circ} \mathrm{C}$. Then, the evaporation rate slowed down significantly, with a MFR of $7.6 \%$ at $200^{\circ} \mathrm{C}$. BBOA showed significant volatility in this study, with an evaporation rate of $0.37 \%{ }^{\circ} \mathrm{C}^{-1}$ near the ambient temperature and an MFR of 0.87 at $50^{\circ} \mathrm{C}$. In addition, it was noted that the evaporation rate of BBOA increased when the TD temperature increased from 100 to $150^{\circ} \mathrm{C}$, indicating that BBOA contained more compounds that favor evaporation in this temperature range. COA showed a similar volatility to that of BBOA, with an MFR of 0.85 at $50^{\circ} \mathrm{C}$, but it kept a stable evaporation rate throughout the whole temperature range $\left(\sim 0.44 \%{ }^{\circ} \mathrm{C}^{-1}\right)$. The volatility of LO-OOA (MFR $=0.70$ at $50^{\circ} \mathrm{C}$ ) was higher than that of MO-OOA (MFR $=0.99$ at $50^{\circ} \mathrm{C}$ ), $\mathrm{COA}$, and BBOA but lower than that of HOA. The MFR curve of MO-OOA remained relatively stable below $100^{\circ} \mathrm{C}$ and then decreased significantly when the temperature increased further. The MFR of MO-OOA was as high as $51.5 \%$ even at $200^{\circ} \mathrm{C}$. Thus, MO-OOA was the least volatile one among the five factors. The OOA (LO-OOA+MO-OOA) in Fig. 6 presents the MFR variation in the combination of LO-OOA and MO-OOA. The MFR of OOA, which is regarded as a good surrogate of SOA, showed a good linear de- 

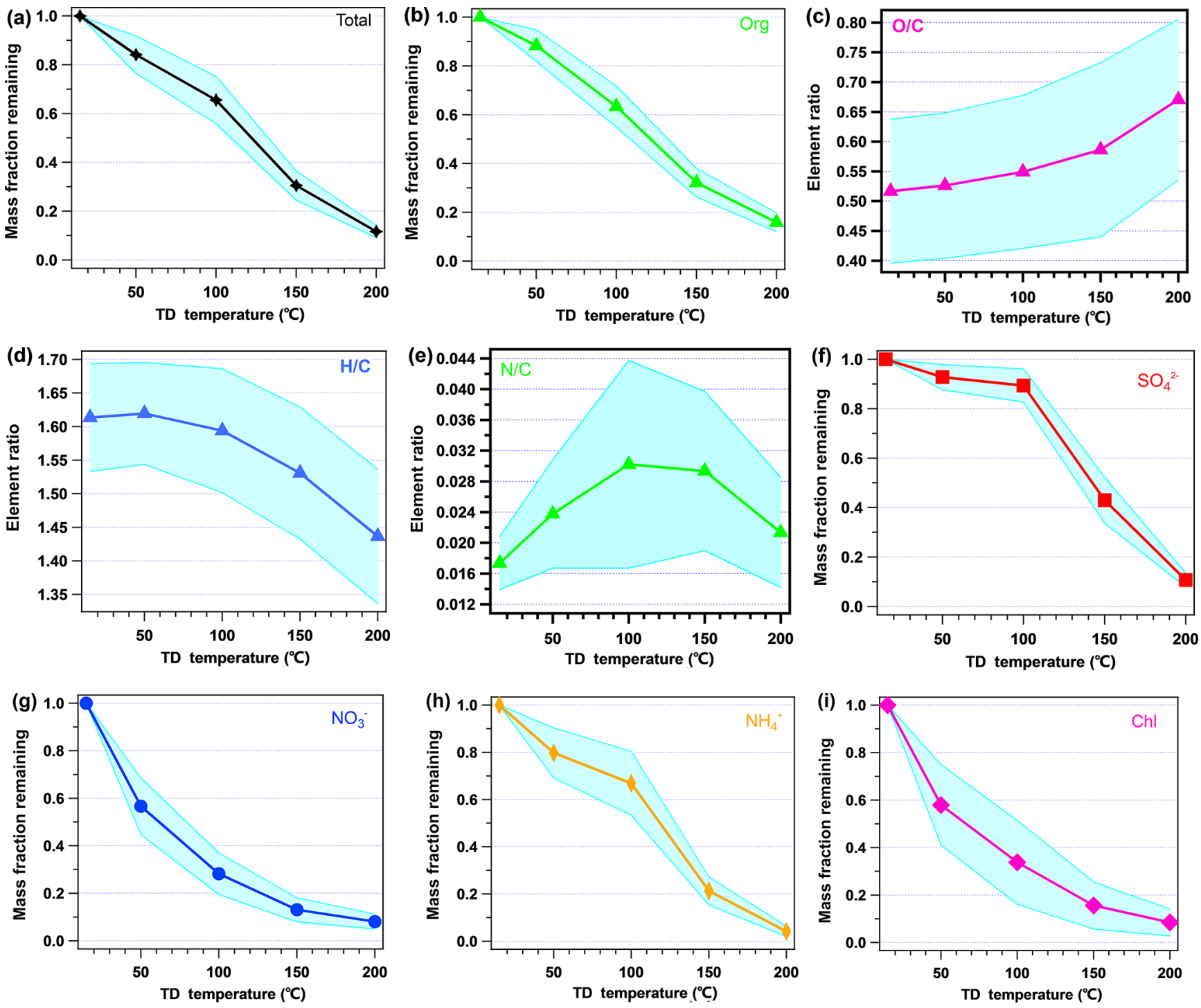

Figure 5. Variation in the average mass fraction remaining (MFR) of the total of non-refractory species and the ratios of $\mathrm{O} / \mathrm{C}$, $\mathrm{H} / \mathrm{C}$, and $\mathrm{N} / \mathrm{C}$ with the TD temperature. The shaded regions indicate the average $\pm \mathrm{SD}$.

cline at the temperatures under $150^{\circ} \mathrm{C}$, with an evaporation rate of $0.54 \%{ }^{\circ} \mathrm{C}^{-1}$. The evaporation rates of the different $\mathrm{OA}$ factors identified by PMF in this study provide the firsthand information of semi-volatility of OAs in China, which will be helpful in constraining parameters in the atmospheric chemical models.

Figure 7 compares both the volatilities (MFR at $50^{\circ} \mathrm{C}$ ) and the $\mathrm{O} / \mathrm{C}$ ratios of the five factors. The sequence of the volatilities can be summarized as HOA $>$ LO-OOA $>$ COA $\approx$ BBOA $>$ MO-OOA. It can be easily found that the sequence of the volatilities of the OA factors does not completely follow the sequence of the $\mathrm{O} / \mathrm{C}$ ratios. For example, although LO-OOA has a higher $\mathrm{O} / \mathrm{C}$ ratio than BBOA and COA, LO-OOA is also more volatile (or with a lower MFR) than BBOA and COA. This clearly indicates the volatil- ity of the OA factors depends on not only the oxygenation of organic compounds but also other factors, e.g., molecular weight and mixing state. HOA is identified as the most volatile $\mathrm{OA}$ factor while MO-OOA is nearly nonvolatile near the real atmospheric temperatures in Shenzhen, which is consistent with the results observed in Mexico and Paris (Cappa and Jimenez, 2010; Paciga et al., 2016). However, LO-OOA is the second most volatile OA factor after HOA in Shenzhen, which is different from that in Mexico, where BBOA is more volatile than LO-OOA. Actually, the volatility of the aerosols directly from biomass burning has been measured to be quite variable, with an evaporation rate of $0.2-1.6 \%{ }^{\circ} \mathrm{C}^{-1}$, depending on the kinds of wood and combustion conditions (Huffman et al., 2009a). The relatively lower volatility of COA was also identified in previous studies and attributed 

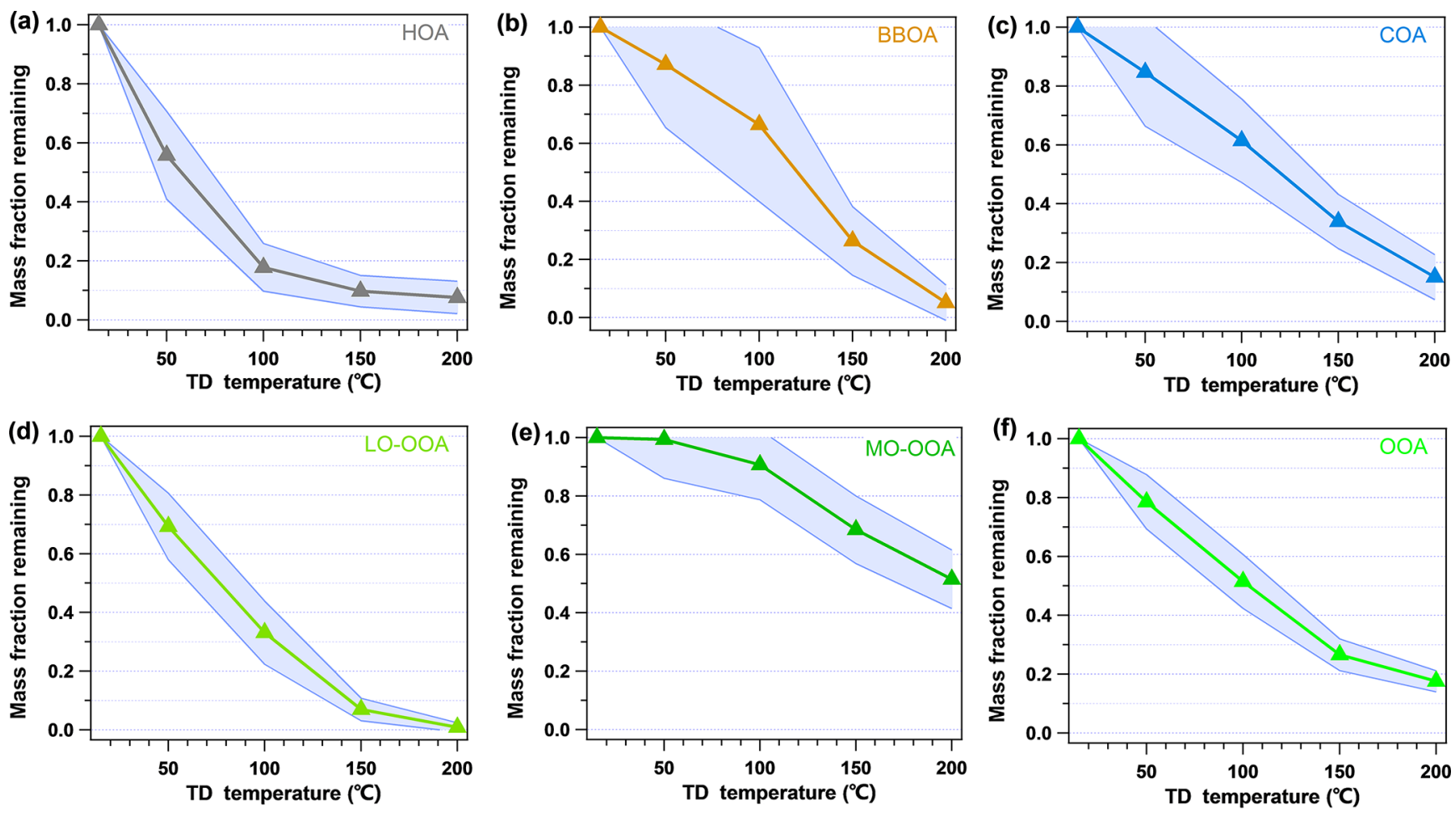

Figure 6. Average mass fraction remaining (MFR) of the five OA factors and OOA (calculated as the combination of MO-OOA and LOOOA). The shaded region is the average $\mathrm{MFR} \pm \mathrm{SD}$.

to the abundant fatty acids of low volatility in COA (Mohr et al., 2009; Paciga et al., 2016). Hong et al. (2017) recently reported the estimation of the OA volatility in a boreal forest in Finland using two independent methods, including using a VTDMA with a kinetic evaporation model and applying PMF to HR-AMS data. Semi-volatile and low-volatility organic mass fractions were determined with both methods, similar to our study in China. This implies that MO-OOA and LO-OOA, with different volatilities, could be popular OA components across the world. Hong et al. (2017) also pointed out that determining extremely low-volatility OAs from AMS data using the PMF analysis should be explored in future studies.

It should also be noted that as the most volatile species in this study, HOA could be evaporated easily and thus have a larger potential to experience the "evaporation - oxidation in gas phase - condensation" process and then form SOA since previous studies showed that semi-volatile hydrocarbons from diesel exhaust (Robinson et al., 2007) and crude oil (de Gouw et al., 2011) can be easily oxidized in the gas phase to form less-volatile SOA. Huang et al. (2012) also pointed out that HOA could be oxidized to SOA based on the analysis of their diurnal variations. This potential can be further supported by the fact that it was difficult to resolve HOA in downwind regions far from urban and industrial areas in China, implying that HOA had been oxidized during the air mass transport (Huang et al., 2011; Zhu et al., 2016). There-

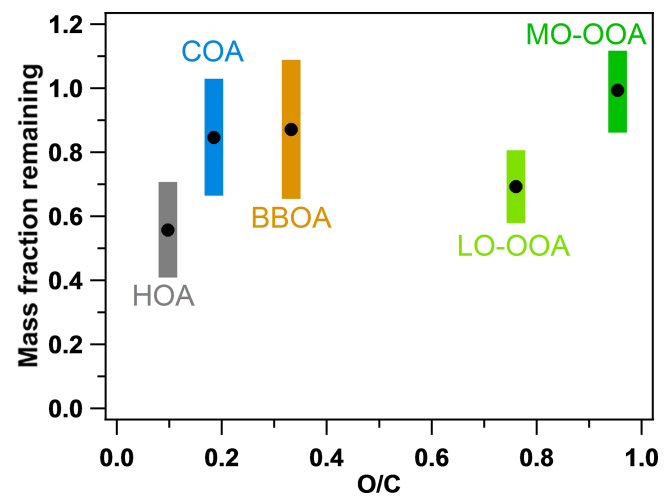

Figure 7. Comparison of the volatilities (MFRs at $50^{\circ} \mathrm{C}$ ) and $\mathrm{O} / \mathrm{C}$ ratios of the five $\mathrm{OA}$ factors in this study. The colorful regions indicate the SDs of the MFRs.

fore, the modeling work needs to consider the process from HOA to SOA in future.

\section{Conclusions}

The source apportionment and volatility of the $\mathrm{PM}_{1}$ chemical composition during winter in Shenzhen were investigated based on the TD-AMS system. The mean $\mathrm{PM}_{1}$ mass concentration was $42.7 \pm 20.1 \mu \mathrm{g} \mathrm{m}^{-3}$ during the experiment, 
with organics (accounting for $43.2 \%$ ) as the most abundant species. Sulfate, BC, nitrate, ammonium, and chloride contributed $21.2,12.2,11.4,10.4$, and $1.6 \%$ to the total $\mathrm{PM}_{1}$, respectively. The chemical species in $\mathrm{PM}_{1}$ exhibited a range of volatilities. Nitrate showed the highest volatility among the five species measured, with the lowest MFR (0.57) at $50^{\circ} \mathrm{C}$. Organics exhibited a relatively linear MFR decrease, with a rate of $0.45 \%{ }^{\circ} \mathrm{C}^{-1}$, as the TD temperature increased from ambient to $200^{\circ} \mathrm{C}$, which is mainly due to the complex composition of organics in the atmosphere. The organics were grouped into five subtypes by the PMF analysis, including primarily emitted HOA, COA, BBOA, and two secondarily formed oxygenated OAs: LO-OOA and MO-OOA, and they accounted for 13.5, 20.6, 8.9, 39.1, and $17.9 \%$ of the total OA, respectively. Among all five OA factors, HOA was the most volatile species, whereas MO-OOA had the lowest volatility with the slowest evaporation rate. According to the MFR of different $\mathrm{OA}$ factors at $50^{\circ} \mathrm{C}$, the volatility sequence of the five OA factors was HOA (MFR of 0.56 at $\left.50{ }^{\circ} \mathrm{C}\right)>\mathrm{LO}-\mathrm{OOA}(0.70)>\mathrm{COA}(0.85) \approx \mathrm{BBOA}$ $(0.87)>$ MO-OOA (0.99), which was not completely consistent with the sequence of their $\mathrm{O} / \mathrm{C}$ ratios. The most volatile HOA had a high potential to be oxidized to secondary species in the gas phase.

Data availability. Datasets are available by contacting the corresponding author, Xiao-Feng Huang (huangxf@pku.edu.cn).

Supplement. The supplement related to this article is available online at: https://doi.org/10.5194/acp-18-1729-2018-supplement.

Competing interests. The authors declare that they have no conflict of interest.

Acknowledgements. This work was supported by the National Natural Science Foundation of China (U1301234, 41622304) and the Science and Technology Plan of Shenzhen Municipality (JCYJ20170412150626172, JCYJ20170306164713148). We thank André S. H. Prévôt of the Paul Scherrer Institute, Switzerland, for providing the code for BC source apportionment.

Edited by: Aijun Ding

Reviewed by: three anonymous referees

\section{References}

Aiken, A. C., DeCarlo, P. F., Kroll, J. H., Worsnop, D. R., Huffman, J. A., Docherty, K. S., Ulbrich, I. M., Mohr, C., Kimmel, J. R., Sueper, D., Sun, Y., Zhang, Q., Trimborn, A., Northway, M., Ziemann, P. J., Canagaratna, M. R., Onasch, T. B., Alfarra, M. R., Prevot, A. S. H., Dommen, J., Duplissy, J., Metzger, A., Baltensperger, U., and Jimenez, J. L.: O/C and $\mathrm{OM} / \mathrm{OC}$ ratios of primary, secondary, and ambient organic aerosols with high resolution time-of-flight aerosol mass spectrometry, Environ. Sci. Technol., 42, 4478-4485, https://doi.org/10.1021/es703009q, 2008.

Aiken, A. C., Salcedo, D., Cubison, M. J., Huffman, J. A., DeCarlo, P. F., Ulbrich, I. M., Docherty, K. S., Sueper, D., Kimmel, J. R., Worsnop, D. R., Trimborn, A., Northway, M., Stone, E. A., Schauer, J. J., Volkamer, R. M., Fortner, E., de Foy, B., Wang, J., Laskin, A., Shutthanandan, V., Zheng, J., Zhang, R., Gaffney, J., Marley, N. A., Paredes-Miranda, G., Arnott, W. P., Molina, L. T., Sosa, G., and Jimenez, J. L.: Mexico City aerosol analysis during MILAGRO using high resolution aerosol mass spectrometry at the urban supersite (T0) - Part 1: Fine particle composition and organic source apportionment, Atmos. Chem. Phys., 9, 6633-6653, https://doi.org/10.5194/acp-9-6633-2009, 2009.

Alfarra, M. R., Prevot, A. S., Szidat, S., Sandradewi, J., Weimer, S., Lanz, V. A., Schreiber, D., Mohr, M., and Baltensperger, U.: Identification of the mass spectral signature of organic aerosols from wood burning emissions, Environ. Sci. Technol., 41, 5770 5777, https://doi.org/10.1021/es062289b, 2007.

An, W. J., Pathak, R. K., Lee, B. H., and Pandis, S. N.: Aerosol volatility measurement using an improved thermodenuder: application to secondary organic aerosol, J. Aerosol Sci., 38, 305-314, https://doi.org/10.1016/j.jaerosci.2006.12.002, 2007.

Baklanov, A., Molina, L. T., and Gauss, M.: Megacities, air quality and climate, Atmos. Environ., 126, 235-249, https://doi.org/10.1016/j.atmosenv.2015.11.059, 2015.

Bidleman, T. F.: Atmospheric processes: wet and dry deposition of organic compounds are controlled by their vaporparticle partitioning, Environ. Sci. Technol., 22, 361-367, https://doi.org/10.1021/es00169a002, 1988.

Bohnenstengel, S. I., Belcher, S. E., Aiken, A., Allan, J. D., Allen, G., Bacak, A., Bannan, T. J., Barlow, J. F., Beddows, D. C. S., Bloss, W. J., Booth, A. M., Chemel, C., Coceal, O., Di Marco, C. F., Dubey, M. K., Faloon, K. H., Fleming, Z. L., Furger, M., Gietl, J. K., Graves, R. R., Green, D. C., Grimmond, C. S. B., Halios, C. H., Hamilton, J. F., Harrison, R. M., Heal, M. R., Heard, D. E., Helfter, C., Herndon, S. C., Holmes, R. E., Hopkins, J. R., Jones, A. M., Kelly, F. J., Kotthaus, S., Langford, B., Lee, J. D., Leigh, R. J., Lewis, A. C., Lidster, R. T., Lopez-Hilfiker, F. D., McQuaid, J. B., Mohr, C., Monks, P. S., Nemitz, E., Ng, N. L., Percival, C. J., Prévôt, A. S. H., Ricketts, H. M. A., Sokhi, R., Stone, D., Thornton, J. A., Tremper, A. H., Valach, A. C., Visser, S., Whalley, L. K., Williams, L. R., Xu, L., Young, D. E., and Zotter, P.: Meteorology, Air Quality, and Health in London: the ClearfLo Project, B. Am. Meteorol. Soc., 96, 779-804, https://doi.org/10.1175/BAMS-D-12-00245.1, 2014.

Burtscher, H., Baltensperger, U., Bukowiecki, N., Cohn, P., Hüglin, C., Mohr, M., Matter, U., Nyeki, S., Schmatloch, V., Streit, N., and Weingartner, E.: Separation of volatile and nonvolatile aerosol fractions by thermos desorption: instrumental 
development and applications, J. Aerosol Sci., 32, 427-442, https://doi.org/10.1016/S0021-8502(00)00089-6, 2001.

Canagaratna, M. R., Jayne, J. T., Ghertner, D. A., Herndon, S., Shi, Q., Jimenez, J. L., Silva, P. J., Williams, P., Lanni, T., Drewnick, F., Demerjian, K. L., Kolb, C. E., and Worsnop, D. R.: Chase studies of particulate emissions from inuse New York City vehicles, Aerosol Sci. Tech., 38, 555-573, https://doi.org/10.1080/02786820490465504, 2004.

Canagaratna, M. R., Jayne, J. T., Jimenez, J. L., Allan, J. D., Alfarra, M. R., Zhang, Q., Onasch, T. B., Drewnick, F., Coe, H., Middlebrook, A., Delia, A., Williams, L. R., Trimborn, A. M., Northway, M. J., DeCarlo, P. F., Kolb, C. E., Davidovits, P., and Worsnop, D. R.: Chemical and microphysical characterization of ambient aerosols with the aerodyne aerosol mass spectrometer, Mass Spectrom. Rev., 26, 185-222, https://doi.org/10.1002/mas.20115, 2007.

Canagaratna, M. R., Jimenez, J. L., Kroll, J. H., Chen, Q., Kessler, S. H., Massoli, P., Hildebrandt Ruiz, L., Fortner, E., Williams, L. R., Wilson, K. R., Surratt, J. D., Donahue, N. M., Jayne, J. T., and Worsnop, D. R.: Elemental ratio measurements of organic compounds using aerosol mass spectrometry: characterization, improved calibration, and implications, Atmos. Chem. Phys., 15, 253-272, https://doi.org/10.5194/acp-15-253-2015, 2015.

Cappa, C. D. and Jimenez, J. L.: Quantitative estimates of the volatility of ambient organic aerosol, Atmos. Chem. Phys., 10, 5409-5424, https://doi.org/10.5194/acp-10-5409-2010, 2010.

Cheung, H. H. Y., Tan, H., Xu, H., Li, F., Wu, C., Yu, J. Z., and Chan, C. K.: Measurements of non-volatile aerosols with a VTDMA and their correlations with carbonaceous aerosols in Guangzhou, China, Atmos. Chem. Phys., 16, 8431-8446, https://doi.org/10.5194/acp-16-8431-2016, 2016.

Crippa, M., Haddad, I. E., Slowik, J. G., Decarlo, P. F., Mohr, C., Heringa, M. F., Chirico, R., Marchand, N., Sciare, J., Baltensperger, U., and Prevot, A. S. H.: Identification of marine and continental aerosol sources in Paris using high resolution aerosol mass spectrometry, J. Geophys. Res.-Atmos., 118, 1950-1963, https://doi.org/10.1002/jgrd.50151, 2013.

Decarlo, P. F., Kimmel, J. R., Trimborn, A., Northway, M. J., Jayne, J. T., Aiken, A. C., Gonin, M., Fuhrer, K., Horvath, T., Docherty, K. S., Worsnop, D. R., and Jimenez, J. L.: Field-deployable, high-resolution, time-offlight aerosol mass spectrometer, Anal. Chem., 78, 8281-8289, https://doi.org/10.1021/ac061249n, 2006.

DeCarlo, P. F., Dunlea, E. J., Kimmel, J. R., Aiken, A. C., Sueper, D., Crounse, J., Wennberg, P. O., Emmons, L., Shinozuka, Y., Clarke, A., Zhou, J., Tomlinson, J., Collins, D. R., Knapp, D., Weinheimer, A. J., Montzka, D. D., Campos, T., and Jimenez, J. L.: Fast airborne aerosol size and chemistry measurements above Mexico City and Central Mexico during the MILAGRO campaign, Atmos. Chem. Phys., 8, 4027-4048, https://doi.org/10.5194/acp-8-4027-2008, 2008.

DeCarlo, P. F., Ulbrich, I. M., Crounse, J., de Foy, B., Dunlea, E. J., Aiken, A. C., Knapp, D., Weinheimer, A. J., Campos, T., Wennberg, P. O., and Jimenez, J. L.: Investigation of the sources and processing of organic aerosol over the Central Mexican Plateau from aircraft measurements during MILAGRO, Atmos. Chem. Phys., 10, 5257-5280, https://doi.org/10.5194/acp10-5257-2010, 2010. de Gouw, J. A. D., Middlebrook, A. M., Warneke, C.,Ahmadov, R., Atlas, E. L., Bahreini, R., Blake, D. R., Brock, C. A.,Brioude, J., Fahey, D. W., Fehsenfeld, F. C., Holloway, J. S., Le Henaff, M., Lueb, R. A., McKeen, S. A., Meagher, J. F., Murphy, D. M., Paris, C., Parrish, D. D., Perring, A. E., Pollack, I. B., Ravishankara, A. R., Robinson, A. L., Ryerson, T. B., Schwarz, J. P., Spackman, J. R., Srinivasan, A., and Watts, L. A.: Organic aerosol formation downwind from the deep water horizon oil spill, Science, 331, 1295-1299, https://doi.org/10.1126/science.1200320, 2011.

Docherty, K. S., Stone, E. A., Ulbrich, I. M., Decarlo, P. F., Snyder, D. C., Schauer, J. J., Peltier, R. E., Weber, R. J., Murphy, S. M., Seinfeld, J. H., Grover, B. D., Eatough, D. J., and Jimenez, J. L.: Apportionment of primary and secondary organic aerosols in southern California during the 2005 study of organic aerosols in riverside (SOAR-1), Environ. Sci. Technol., 42, 7655-7662, https://doi.org/10.1021/es8008166, 2008.

Donahue, N. M., Robinson, A. L., Stanier, C. O., and Pandis, S., N.: Coupled partitioning, dilution, and chemical aging of semivolatile organics, Environ. Sci. Technol., 40, 2635-2643, https://doi.org/10.1021/es052297c, 2006.

Drewnick, F., Hings, S. S., DeCarlo, P., Jayne, J. T., Gonin, M., Fuhrer, K., Weimer, S., Jimenez, J. L., Demerjian, K. L., Borrmann, S., and Worsnop, D. R.: A new time-of-flight aerosol mass spectrometer (ToF-AMS) - instrument description and first field deployment, Aerosol Sci. Tech., 39, 637-658, https://doi.org/10.1080/02786820500182040, 2005.

Elser, M., Huang, R.-J., Wolf, R., Slowik, J. G., Wang, Q., Canonaco, F., Li, G., Bozzetti, C., Daellenbach, K. R., Huang, Y., Zhang, R., Li, Z., Cao, J., Baltensperger, U., El-Haddad, I., and Prévôt, A. S. H.: New insights into $\mathrm{PM}_{2.5}$ chemical composition and sources in two major cities in China during extreme haze events using aerosol mass spectrometry, Atmos. Chem. Phys., 16, 3207-3225, https://doi.org/10.5194/acp-16-3207-2016, 2016.

Hallquist, M., Wenger, J. C., Baltensperger, U., Rudich, Y., Simpson, D., Claeys, M., Dommen, J., Donahue, N. M., George, C., Goldstein, A. H., Hamilton, J. F., Herrmann, H., Hoffmann, T., Iinuma, Y., Jang, M., Jenkin, M. E., Jimenez, J. L., Kiendler-Scharr, A., Maenhaut, W., McFiggans, G., Mentel, Th. F., Monod, A., Prévôt, A. S. H., Seinfeld, J. H., Surratt, J. D., Szmigielski, R., and Wildt, J.: The formation, properties and impact of secondary organic aerosol: current and emerging issues, Atmos. Chem. Phys., 9, 5155-5236, https://doi.org/10.5194/acp9-5155-2009, 2009.

He, L.-Y., Lin, Y., Huang, X.-F., Guo, S., Xue, L., Su, Q., Hu, M., Luan, S.-J., and Zhang, Y.-H.: Characterization of highresolution aerosol mass spectra of primary organic aerosol emissions from Chinese cooking and biomass burning, Atmos. Chem. Phys., 10, 11535-11543, https://doi.org/10.5194/acp-10-115352010, 2010.

He, L. Y., Huang, X. F., Xue, L., Hu, M., Lin, Y., Zheng, J., Zhang, R., and Zhang, Y. H.: Submicron aerosol analysis and organic source apportionment in an urban atmosphere in Pearl River Delta of China using high-resolution aerosol mass spectrometry, J. Geophys. Res.-Atmos., 116, 1248-1256, https://doi.org/10.1029/2010JD014566, 2011.

Hong, J., Äijälä, M., Häme, S. A. K., Hao, L., Duplissy, J., Heikkinen, L. M., Nie, W., Mikkilä, J., Kulmala, M., Prisle, N. L., Virtanen, A., Ehn, M., Paasonen, P., Worsnop, D. R., Riipinen, I., 
Petäjä, T., and Kerminen, V.-M.: Estimates of the organic aerosol volatility in a boreal forest using two independent methods, Atmos. Chem. Phys., 17, 4387-4399, https://doi.org/10.5194/acp17-4387-2017, 2017.

Hu, W., Campuzano-Jost, P., Day, D. A., Croteau, P., Canagaratna, M. R., Jayne, J. T., Worsnop, D. R., and Jimenez, J. L.: Evaluation of the new capture vaporizer for aerosol mass spectrometers (AMS) through field studies of inorganic species, Aerosol Sci. Tech., 51, 735-754, https://doi.org/10.1080/02786826.2017.1296104, 2017.

Hu, W. W., Hu, M., Hu, W., Jimenez, J. L., Yuan, B., Chen, W. T., Wang, M., Wu, Y. S., Chen, C., Wang, Z. B., Peng, J. F., Zeng, L. M., and Shao, M.: Chemical composition, sources, and aging process of submicron aerosols in Beijing: contrast between summer and winter, J. Geophys. Res.-Atmos., 121, 1955-1977, https://doi.org/10.1002/2015JD024020, 2016.

Huang, X.-F. and Yu, J. Z.: Size distributions of elemental carbon in the atmosphere of a coastal urban area in South China: characteristics, evolution processes, and implications for the mixing state, Atmos. Chem. Phys., 8, 5843-5853, https://doi.org/10.5194/acp8-5843-2008, 2008.

Huang, X.-F., He, L.-Y., Hu, M., Canagaratna, M. R., Sun, Y., Zhang, Q., Zhu, T., Xue, L., Zeng, L.-W., Liu, X.-G., Zhang, Y.-H., Jayne, J. T., Ng, N. L., and Worsnop, D. R.: Highly time-resolved chemical characterization of atmospheric submicron particles during 2008 Beijing Olympic Games using an Aerodyne High-Resolution Aerosol Mass Spectrometer, Atmos. Chem. Phys., 10, 8933-8945, https://doi.org/10.5194/acp-108933-2010, 2010.

Huang, X.-F., He, L.-Y., Hu, M., Canagaratna, M. R., Kroll, J. H., Ng, N. L., Zhang, Y.-H., Lin, Y., Xue, L., Sun, T.L., Liu, X.-G., Shao, M., Jayne, J. T., and Worsnop, D. R.: Characterization of submicron aerosols at a rural site in Pearl River Delta of China using an Aerodyne High-Resolution Aerosol Mass Spectrometer, Atmos. Chem. Phys., 11, 18651877, https://doi.org/10.5194/acp-11-1865-2011, 2011.

Huang, X.-F., He, L.-Y., Xue, L., Sun, T.-L., Zeng, L.-W., Gong, Z.-H., Hu, M., and Zhu, T.: Highly time-resolved chemical characterization of atmospheric fine particles during 2010 Shanghai World Expo, Atmos. Chem. Phys., 12, 4897-4907, https://doi.org/10.5194/acp-12-4897-2012, 2012.

Huang, X. F., Xue, L., Tian, X. D., Shao, W. W., Sun, T. L., Gong, Z. H., Ju, W- W., Jiang, B., Hu, M., and He, L. Y.: Highly time-resolved carbonaceous aerosol characterization in Yangtze River Delta of China: composition, mixing state and secondary formation, Atmos. Environ., 64, 200-207, https://doi.org/10.1016/j.atmosenv.2012.09.059, 2013.

Huang, X. F., Yun, H., Gong, Z. H., Li, X., He, L. Y., Zhang, Y. H., and Hu, M.: Source apportionment and secondary organic aerosol estimation of $\mathrm{PM}_{2.5}$ in an urban atmosphere in China, Sci. China Earth Sci., 57, 1352-1362, https://doi.org/10.1007/s11430-013-4686-2, 2014.

Huffman, J. A., Ziemann, P. J., Jayne, J. T., Worsnop, D. R., and Jimenez, J. L.: Development and characterization of a fast-stepping/scanning thermodenuder for chemically-resolved aerosol volatility measurements, Aerosol Sci. Tech., 42, 395407, https://doi.org/10.1080/02786820802104981, 2008.

Huffman, J. A., Docherty, K. S., Mohr, C., Cubison, M. J., Ulbrich, I. M., Ziemann, P. J., Onasch, T. B., and Jimenez, J. L.:
Chemically-resolved volatility measurements of organic aerosol from different sources, Environ. Sci. Technol., 43, 5351-5357, https://doi.org/10.1021/es803539d, 2009a.

Huffman, J. A., Docherty, K. S., Aiken, A. C., Cubison, M. J., Ulbrich, I. M., DeCarlo, P. F., Sueper, D., Jayne, J. T., Worsnop, D. R., Ziemann, P. J., and Jimenez, J. L.: Chemically-resolved aerosol volatility measurements from two megacity field studies, Atmos. Chem. Phys., 9, 7161-7182, https://doi.org/10.5194/acp9-7161-2009, 2009b.

IPCC: Climate Change: The Physical Science Basis - Contribution of Working Group I to the Fifth Assessment Report of the Intergovernmental Panel on Climate Change, edited by: Stocker, T. F., Qin, D., Plattner, G. K., Tignor, M., Allen, S. K., Boschung, J., Nauels, A., Xia, Y., Bex, V., and Midgley, P. M., Cambridge University Press, Cambridge, UK and New York, NY, USA, 1535 pp., 2013.

Jayne, J. T., Leard, D. C., Zhang, X. F., Davidovits, P., Smith, K. A., Kolb, C. E., and Worsnop, D. R.: Development of an aerosol mass spectrometer for size and composition analysis of submicron particles, Aerosol Sci. Tech., 33, 49-70, https://doi.org/10.1080/027868200410840, 2000.

Jimenez, J. L., Jayne, J. T., Shi, Q., Kolb, C. E., Worsnop, D. R., Yourshaw, I., Seinfeld, J. H., Flagan, R. C., Zhang, X. F., Smith, K. A., Morris, J. W., and Davidovits, P.: Ambient aerosol sampling using the aerodyne aerosol mass spectrometer, J. Geophys. Res.-Atmos., 108, 447-457, https://doi.org/10.1029/2001JD001213, 2003.

Jimenez, J. L., Canagaratna, M. R., Donahue, N. M., Prevot, A. S. H., Zhang, Q., Kroll, J. H., DeCarlo, P. F., Allan, J. D., Coe, H., Ng, N. L., Aiken, A. C., Docherty, K. S., Ulbrich, I. M.,Grieshop, A. P., Robinson, A. L., Duplissy, J., Smith, J. D., Wilson, K. R., Lanz, V. A., Hueglin, C., Sun, Y. L., Tian, J., Laaksonen, A., Raatikainen, T., Rautiainen, J., Vaattovaara, P., Ehn, M., Kulmala, M., Tomlinson, J. M., Collins, D. R., Cubison, M. J., Dunlea, E. J., Huffman, J. A., Onasch, T. B., Alfarra, M. R.,Williams, P. I., Bower, K., Kondo, Y., Schneider, J., Drewnick, F., Borrmann, S., Weimer, S., Demerjian, K., Salcedo, D., Cottrell, L., Griffin, R., Takami, A., Miyoshi, T., Hatakeyama, S., Shimono, A., Sun, J. Y., Zhang, Y. M., Dzepina, K., Kimmel, J. R., Sueper, D., Jayne, J. T., Herndon, S. C., Trimborn, A. M., Williams, L. R., Wood, E. C., Middlebrook, A. M., Kolb, C. E., Baltensperger, U., and Worsnop, D. R.: Evolution of organic aerosols in the atmosphere, Science, 326, 1525-1529, https://doi.org/10.1126/science.1180353, 2009.

Kuwata, M., Zorn, S. R., and Martin, S. T.: Using elemental ratios to predict the density of organic material composed of carbon, hydrogen, and oxygen, Environ. Sci. Technol., 46, 787-94, https://doi.org/10.1021/es202525q, 2012.

Lan, Z. J., Chen, D. L., Li, X., Huang, X. F., He, L. Y., Deng, Y. G., Feng, N., and Hu, M.: Modal characteristics of carbonaceous aerosol size distribution in an urban atmosphere of South China, Atmos. Res., 100, 51-60, https://doi.org/10.1016/j.atmosres.2010.12.022, 2011.

Lanz, V. A., Alfarra, M. R., Baltensperger, U., Buchmann, B., Hueglin, C., and Prévôt, A. S. H.: Source apportionment of submicron organic aerosols at an urban site by factor analytical modelling of aerosol mass spectra, Atmos. Chem. Phys., 7, 15031522, https://doi.org/10.5194/acp-7-1503-2007, 2007. 
Lee, B. H., Kostenidou, E., Hildebrandt, L., Riipinen, I., Engelhart, G. J., Mohr, C., DeCarlo, P. F., Mihalopoulos, N., Prevot, A. S. H., Baltensperger, U., and Pandis, S. N.: Measurement of the ambient organic aerosol volatility distribution: application during the Finokalia Aerosol Measurement Experiment (FAME-2008), Atmos. Chem. Phys., 10, 12149-12160, https://doi.org/10.5194/acp-10-12149-2010, 2010.

Lee, B. P., Li, Y. J., Yu, J. Z., Louie, P. K. K., and Chan, C. K.: Physical and chemical characterization of ambient aerosol by HR-ToF-AMS at a suburban site in Hong Kong during springtime 2011, J. Geophys. Res.-Atmos., 118, 8625-8639, https://doi.org/10.1002/jgrd.50658, 2013.

Li, Y. J., Sun, Y., Zhang, Q., Li, X., Li, M., Zhou, Z., and Chan, C. K.: Real-time chemical characterization of atmospheric particulate matter in China: a review, Atmos. Environ., 158, 270 304, https://doi.org/10.1016/j.atmosenv.2017.02.027, 2017.

Middlebrook, A. M., Bahreini, R., Jimenez, J. L., and Canagaratna, M. R.: Evaluation of composition-dependent collection efficiencies for the aerodyne aerosol mass spectrometer using field data, Aerosol Sci. Tech., 46, 258-271, https://doi.org/10.1080/02786826.2011.620041, 2012.

Mohr, C., Huffman, J. A., Cubison, M. J., Aiken, A. C., Docherty, K. S.,Kimmel, J. R., Ulbrich, I. M., Hannigan, M., and Jimenez, J. L.: Characterization of primary organic aerosol emissions from meat cooking, trash burning, and motor vehicles with high-resolution aerosol mass spectrometry and comparison with ambient and chamber observations, Environ. Sci. Technol., 43, 2443-2449, https://doi.org/10.1021/es8011518, 2009.

Mohr, C., DeCarlo, P. F., Heringa, M. F., Chirico, R., Slowik, J. G., Richter, R., Reche, C., Alastuey, A., Querol, X., Seco, R., Peñuelas, J., Jiménez, J. L., Crippa, M., Zimmermann, R., Baltensperger, U., and Prévôt, A. S. H.: Identification and quantification of organic aerosol from cooking and other sources in Barcelona using aerosol mass spectrometer data, Atmos. Chem. Phys., 12, 1649-1665, https://doi.org/10.5194/acp-121649-2012, 2012.

Ng, N. L., Canagaratna, M. R., Zhang, Q., Jimenez, J. L., Tian, J., Ulbrich, I. M., Kroll, J. H., Docherty, K. S., Chhabra, P. S., Bahreini, R., Murphy, S. M., Seinfeld, J. H., Hildebrandt, L., Donahue, N. M., DeCarlo, P. F., Lanz, V. A., Prévôt, A. S. H., Dinar, E., Rudich, Y., and Worsnop, D. R.: Organic aerosol components observed in Northern Hemispheric datasets from Aerosol Mass Spectrometry, Atmos. Chem. Phys., 10, 46254641, https://doi.org/10.5194/acp-10-4625-2010, 2010.

Nie, W., Hong, J., Häme, S. A. K., Ding, A., Li, Y., Yan, C., Hao, L., Mikkilä, J., Zheng, L., Xie, Y., Zhu, C., Xu, Z., Chi, X., Huang, X., Zhou, Y., Lin, P., Virtanen, A., Worsnop, D. R., Kulmala, M., Ehn, M., Yu, J., Kerminen, V.-M., and Petäjä, T.: Volatility of mixed atmospheric humic-like substances and ammonium sulfate particles, Atmos. Chem. Phys., 17, 3659-3672, https://doi.org/10.5194/acp-17-3659-2017, 2017.

Paatero, P. and Hopke, P. K.: Discarding or downweighting highnoise variables in factor analytic models, Anal. Chim. Acta, 490, 277-289, https://doi.org/10.1016/S0003-2670(02)01643-4, 2003.

Paciga, A., Karnezi, E., Kostenidou, E., Hildebrandt, L., Psichoudaki, M., Engelhart, G. J., Lee, B.-H., Crippa, M., Prévôt, A. S. H., Baltensperger, U., and Pandis, S. N.: Volatility of organic aerosol and its components in the megacity of Paris, At- mos. Chem. Phys., 16, 2013-2023, https://doi.org/10.5194/acp16-2013-2016, 2016.

Pankow, J. F. and Badsanti, K. C.: The carbon numberpolarity grid: a means to manage the complexity of the mix of organic compounds when modeling atmospheric organic particular matter, Atmos. Environ., 43, 2829-2835, https://doi.org/10.1016/j.atmosenv.2008.12.050, 2009.

Poulain, L., Birmili, W., Canonaco, F., Crippa, M., Wu, Z. J., Nordmann, S., Spindler, G., Prévôt, A. S. H., Wiedensohler, A., and Herrmann, H.: Chemical mass balance of $300^{\circ} \mathrm{C}$ non-volatile particles at the tropospheric research site Melpitz, Germany, Atmos. Chem. Phys., 14, 10145-10162, https://doi.org/10.5194/acp-14-10145-2014, 2014.

Robinson, A. L., Donahue, N. M., Shrivastava M, K., Weitkamp, E. A., Sage A, M., Grieshop, A. P., Lane, T. E., Pierce, J. R., and Pandis, S. N.: Rethinking organic aerosols: semivolatile emissions and photochemical aging, Science, 315, 1259-1262, https://doi.org/10.1126/science.1133061, 2007.

Sandradewi, J., Prévôt, A. S. H., Szidat, S., Perron, N., Alfarra, M. R., Lanz, V. A., Weingartner, E., and Baltensperger, U.: Using aerosol light absorption measurements for the quantitative determination of wood burning and traffic emission contributions to particulate matter, Environ. Sci. Technol., 42, 3316-23, https://doi.org/10.1021/es702253m, 2008.

Sun, Y.-L., Zhang, Q., Schwab, J. J., Demerjian, K. L., Chen, W.N., Bae, M.-S., Hung, H.-M., Hogrefe, O., Frank, B., Rattigan, O. V., and Lin, Y.-C.: Characterization of the sources and processes of organic and inorganic aerosols in New York city with a high-resolution time-of-flight aerosol mass apectrometer, Atmos. Chem. Phys., 11, 1581-1602, https://doi.org/10.5194/acp11-1581-2011, 2011.

Ulbrich, I. M., Canagaratna, M. R., Zhang, Q., Worsnop, D. R., and Jimenez, J. L.: Interpretation of organic components from Positive Matrix Factorization of aerosol mass spectrometric data, Atmos. Chem. Phys., 9, 2891-2918, https://doi.org/10.5194/acp-92891-2009, 2009.

Wehner, B., Philippin, S., and Wiedensohler, A.: Design and calibration of a thermodenuder with an improved heating unit to measure the size-dependent volatile fraction of aerosol particles, J. Aerosol Sci., 33, 1087-1093, https://doi.org/10.1016/S00218502(02)00056-3, 2002.

Xu, J., Zhang, Q., Chen, M., Ge, X., Ren, J., and Qin, D.: Chemical composition, sources, and processes of urban aerosols during summertime in northwest China: insights from high-resolution aerosol mass spectrometry, Atmos. Chem. Phys., 14, 1259312611, https://doi.org/10.5194/acp-14-12593-2014, 2014.

$\mathrm{Xu}$, L., Suresh, S., Guo, H., Weber, R. J., and Ng, N. L.: Aerosol characterization over the southeastern United States using high-resolution aerosol mass spectrometry: spatial and seasonal variation of aerosol composition and sources with a focus on organic nitrates, Atmos. Chem. Phys., 15, 7307-7336, https://doi.org/10.5194/acp-15-7307-2015, 2015.

Xu, L., Williams, L. R., Young, D. E., Allan, J. D., Coe, H., Massoli, P., Fortner, E., Chhabra, P., Herndon, S., Brooks, W. A., Jayne, J. T., Worsnop, D. R., Aiken, A. C., Liu, S., Gorkowski, K., Dubey, M. K., Fleming, Z. L., Visser, S., Prévôt, A. S. H., and Ng, N. L.: Wintertime aerosol chemical composition, volatility, and spatial variability in the greater London area, Atmos. Chem. Phys., 16, 1139-1160, https://doi.org/10.5194/acp-16-1139-2016, 2016 a. 
Xu, J., Shi, J., Zhang, Q., Ge, X., Canonaco, F., Prévôt, A. S. H., Vonwiller, M., Szidat, S., Ge, J., Ma, J., An, Y., Kang, S., and Qin, D.: Wintertime organic and inorganic aerosols in Lanzhou, China: sources, processes, and comparison with the results during summer, Atmos. Chem. Phys., 16, 14937-14957, https://doi.org/10.5194/acp-16-14937-2016, $2016 \mathrm{~b}$.

Zhang, Q., Worsnop, D. R., Canagaratna, M. R., and Jimenez, J. L.: Hydrocarbon-like and oxygenated organic aerosols in Pittsburgh: insights into sources and processes of organic aerosols, Atmos. Chem. Phys., 5, 3289-3311, https://doi.org/10.5194/acp-5-32892005, 2005.

Zhang, Q., Jimenez, J. L., Canagaratna, M. R., Allan, J. D., Coe, H., Ulbrich, I., Alfarra, M. R., Takami, A., Middlebrook, A. M., Sun, Y. L., Dzepina, K., Dunlea, E., Docherty, K., De-Carlo, P. F., Salcedo, D., Onasch, T., Jayne, J. T., Miyoshi, T., Shimono, A., Hatakeyama, S., Takegawa, N., Kondo, Y., Schneider, J., Drewnick, F., Borrmann, S., Weimer, S., Demerjian, K., Williams, P., Bower, K., Bahreini, R., Cottrell, L., Griffin, R. J., Rautiainen, J., Sun, J. Y., Zhang, Y. M., and Worsnop, D. R.: Ubiquity and dominance of oxygenated species in organic aerosols in anthropogenically-influenced Northern Hemisphere midlatitudes, Geophys. Res. Lett., 34, L13801, https://doi.org/10.1029/2007g1029979, 2007a.
Zhang, Q., Jimenez, J. L., Worsnop, D. R., and Canagaratna, M.: A case study of urban particle acidity and its influence on secondary organic aerosol, Environ. Sci. Technol., 41, 3213-3219, https://doi.org/10.1021/es061812j, 2007b.

Zhu, Q., He, L.-Y., Huang, X.-F., Cao, L.-M., Gong, Z.-H., Wang, C., Zhuang, X., and Hu, M.: Atmospheric aerosol compositions and sources at two national background sites in northern and southern China, Atmos. Chem. Phys., 16, 10283-10297, https://doi.org/10.5194/acp-16-10283-2016, 2016. 